
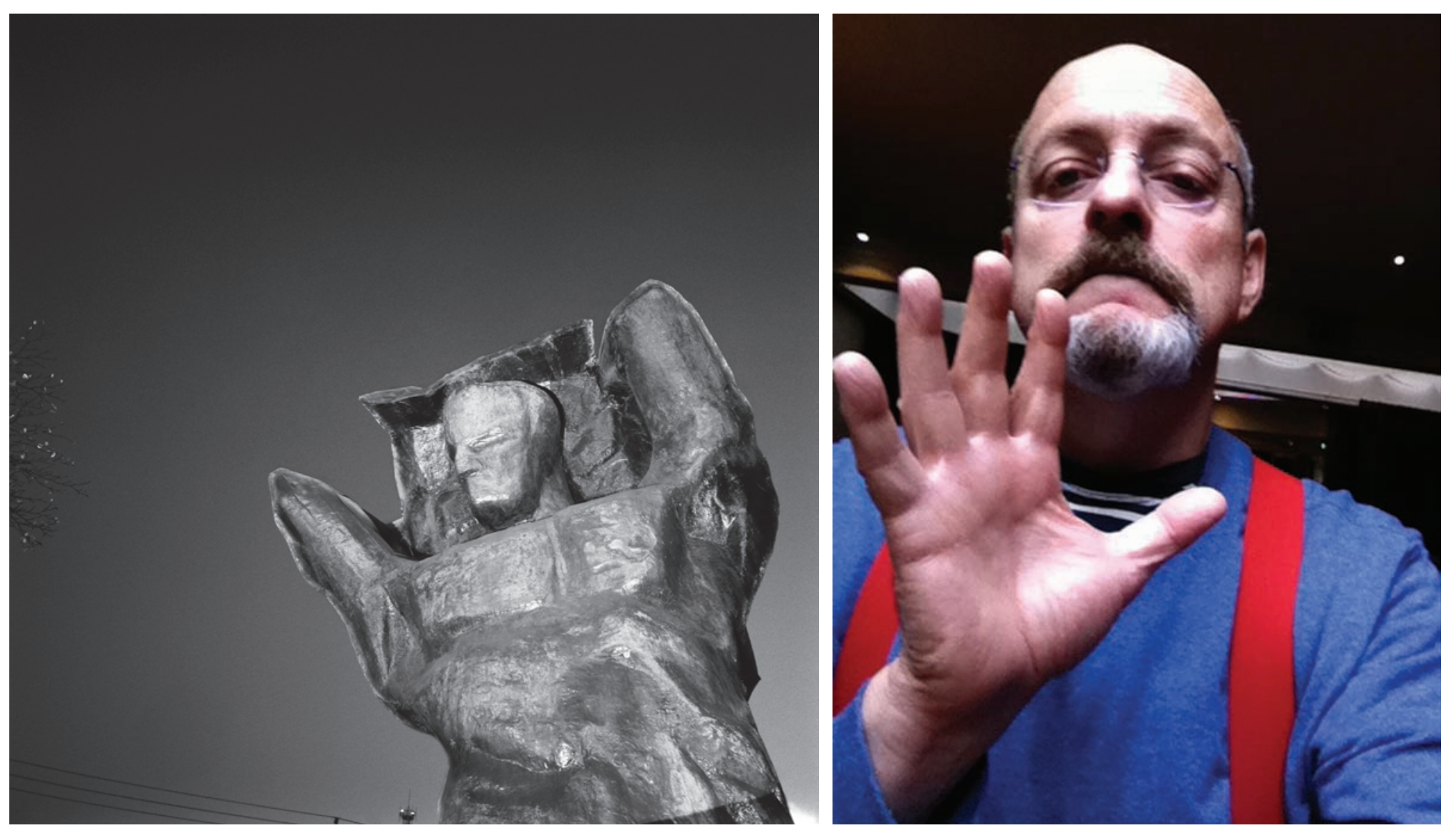

Figure 1: Allan Sekula, Dockers' Monument (Santos), 2010, pigment ink print on archival paper, $76 \times 76 \mathrm{~cm}$. Part of Ship of Fools (2010). (OThe Estate of Allan Sekula. Collection M HKA, Antwerp, Belgium.

Figure 3: Allan Sekula, Ant-Werpen, 2012, low resolution IPhone photograph. (C) The Estate of Allan Sekula. 


\section{Allan Sekula: Imagining a collective future}

1. I would like to thank Sally Stein, Katie Shapiro, and $\mathrm{M}$ HKA for providing illustrations accompanying this text and Marie Muracciole for having shared ideas.

\begin{abstract}
Overall, I had in mind a set of oppositions between grandiose gestures and smaller, intimate, more everyday gestures, between celebrity and anonymity, and between what the American painter and film critic Manny Farber termed 'white elephant art' and 'termite art'.
\end{abstract}

(Sekula 2003: 109)

Those who had the chance to know him during his lifetime have no doubt that Allan Sekula was endowed with an inexhaustible creative drive. Although he has left us a vast body of work, he always had many more ideas to share than he was ultimately able to realize. Up until the last weeks of his life, he remained full of plans and continued to offer information about what he intended to produce next. Underlying the artistic process that Sekula set in motion in the early 1970s was an accumulative principle: each new piece - be it a photographic sequence, a text or a film - deliberately built upon previous work, engaging in dialogue with it. Famously, he identified this as a 'larger montage' at play within his oeuvre (Risberg 1999: 238).

Artistic creation for Sekula was never inhibited by the myth of genius. He incessantly found inspiration in the world around him, particularly in the social reality of the globalized economy. 
He investigated closely how the everyday circumstances of life - especially in the realm of work exercised a profound and often disturbing impact on human beings. He was eager to comment on how the political apparatus often responded inadequately to the course of events, and he did so sharply. He also did not shy away from including autobiographical references when formulating his militant artistic critique of the military complex.

On repeated occasions, he expressed profound concern about the current ecological condition of the earth. As an impressive intellectual glutton he could engage in debate about almost any subject, from taxation policy to engineering techniques. As an extraordinarily experienced traveller he had an exceptional empirical knowledge of the world, both on land and at sea. He visited places that were supposedly invisible: thus he found a reputed CIA black site in Poland. He raised debate about forgotten wars, such as in Laos, where he broke his leg (and integrated this frightening event into the film he made for this often ignored country).

Above all, Sekula will be remembered for his empathy with seafarers, working in situations of hard manual labour and often under highly exploitative conditions. He also strongly identified with nineteenth-century social realism in art (Van Gelder 2005). This was a legacy he actively sought to breathe new life into, judging it to be highly relevant as an artistic tool for engagement in dialogue about the state of today's world. In 2005, for example, he first exhibited Shipwreck and Workers, a large outdoor, multi-panel billboard installation, which he identified as a 'portable and temporary "monument for labor"' (Ruchel-Stockmans 2006: 141). He added - somewhat cynically - that the reason behind this choice for the transformability of his monument was that he, as an artist, was thus 'keeping in line with the prevailing neo-liberal ethos - I'm being "flexible"'.

His brilliant, open mind was always restless and saved no effort in paying tribute to what he called the 'unwaged collective Sisyphus'. ${ }^{2}$ Sekula often recalled his fascination with 'dead labour', by which he meant all of the work done over the course of centuries by innumerable people, which has piled up only to be lost irreversibly in history. ${ }^{3}$ He identified Walking on Water (1990/1995) - a projection of 80 diapositives accompanied by a text about Poland at the end of the Socialist Block, which forms the ninth chapter of his much acclaimed Fish Story (1990-1995) - as the preeminent photographic sequence in which he shared this incessant 'looking for relics' publically. ${ }^{4}$ In line with great sources of inspiration such as Etienne de la Boétie's The Politics of Obedience: The Discourse of Voluntary Servitude (ca. 1552-1553), and the indignation of Simone Weil's 'Meditation on obedience and liberty' (1937-1938), Sekula revolted against that apparently natural law of social balance according to which, as Weil put it, 'the gramme [weighs] heavier than the kilogramme' (Weil 2001: 133).

During his last years, Sekula found in the figure of the dock-worker an optimal personification and defining locus of his work. The docker constantly finds himself in between the worlds of land and sea - like Sekula himself for most of his life. Since 2010, after completing the magnificent film The Forgotten Space with Noël Burch, he set to work on a long-term project that came to be titled The
2. Allan Sekula, in an e-mail to Roger Buergel and Ruth Noack, as quoted in

Van Gelder (2007: 237)

3. Conversation with the author in the artist's studio, Los Angeles, 1 June 12013.

4. A selection of seventeen slides accompanied by a full list of titles is included in Sekula (2009: 74-97.) 
5. Allan Sekula and I were collaborating on the publication of a book entitled Ship of Fools/The Dockers' Museum, a project that is in the process of being completed in his absence and which is scheduled to be published by Leuven University Press in 2014.

6. Conversation between the author and the artist at his home in Los Angeles on 5 June 2013. For more information on this engagement with the figure of Hercules, cf. Van Gelder (2007)

7. The information in the following paragraphs was gathered from various conversations with Allan Sekula in May-June 2013 but, most specifically, from a conversation we had on 30 May 2013 at his home.

8. Titanic's Wake is published, along with Dear Bill Gates (1999) and Waiting for Tear Gas (1999/2000) in Sekula (2003).
Dockers' $^{\prime}$ Museum. ${ }^{5}$ This consists of a wide variety of objects that were bought online or at flea markets, includes text fragments written by Sekula, slide projections and a sequence of photographs called Ship of Fools (2010) made in the Brazilian port of Santos and whilst travelling at sea between 1999 and 2009 (Figure 1).

The idea of dedicating an 'imaginary museum' to the figure of the docker, Sekula emphasized in conversation, arose concretely out of his fascination for the figure of Hercules, with which he engaged at Documenta 12 in Kassel in 2007 on the occasion of presenting the third version of Shipwreck and Workers. ${ }^{6}$ After Kassel, whilst frequenting many different ports during the filming of The Forgotten Space, the figures of Hercules and the docker began to coalesce in Sekula's mind working on the docks being one of the hardest modes of physical labour. Whilst selecting objects for The Dockers' Museum, in particular the many postcards it includes, Sekula felt that a 'vision of history' was revealed to him (Figure 2). ${ }^{7}$ This vision preoccupied his work during the last years of his life: from a microscopic perspective combining specific elements organized around one theme, namely, the docker, to a macroscopic perspective on the contemporary situation of the world.

Sekula considered The Dockers' Museum to be a 'sample, an asset of a physical and social process, in order to see where it's at'; a methodological approach, he recalled, that was familiar from earlier works such as Fish Story. Moreover, the theme of the docker was already present, embryonically, in Fish Story. The project that stands as a bridge between Fish Story and The Dockers' Museum is Titanic's Wake (1998/2000) which, he insisted, was 'the project that won't go away'. ${ }^{8}$ Ten years after the Seattle protests of 30 November 1999, he decided to investigate 'what one can assess from that'. How can one 'ascertain what has actually happened since then?' These are the principal stakes of both Ship of Fools and The Dockers' Museum.

Whilst working on Titanic's Wake, Sekula travelled on a ship named The Global Mariner which is, as he described it, an '18,000 deadweight-ton general cargo vessel carrying in its converted holds a remarkable exhibition about working conditions at sea, and - in a broader sense - about the hidden social costs and probable consequences of corporate globalization' (Sekula 2003: 33). The Global Mariner was stigmatized by its critics as a 'toy ship'. Yet, for Sekula, it was the 'good ship', which he opposed to those 'bad ships' that sail under convenience flags and exploit their crews like slaves. The title Ship of Fools refers directly to this. It is taken from Sebastian Brant's late fifteenth-century book Narrenschiff, which Sekula wittily identified as the 'Family of man of the incunabula'. Ship of Fools/The Dockers' Museum have sadly turned out to be Sekula's last project. Intended as 'a moral instruction, a parable about human nature', this is a 'phantasmatic project' in which the artist invents himself as an 'imaginary proletarian [...] imagining the object world of an imaginary collective community'.

Sekula's sympathy for and empathy with what was initially called the anti-globalization movement is well documented. The way the world has developed since the era of Margaret Thatcher and 


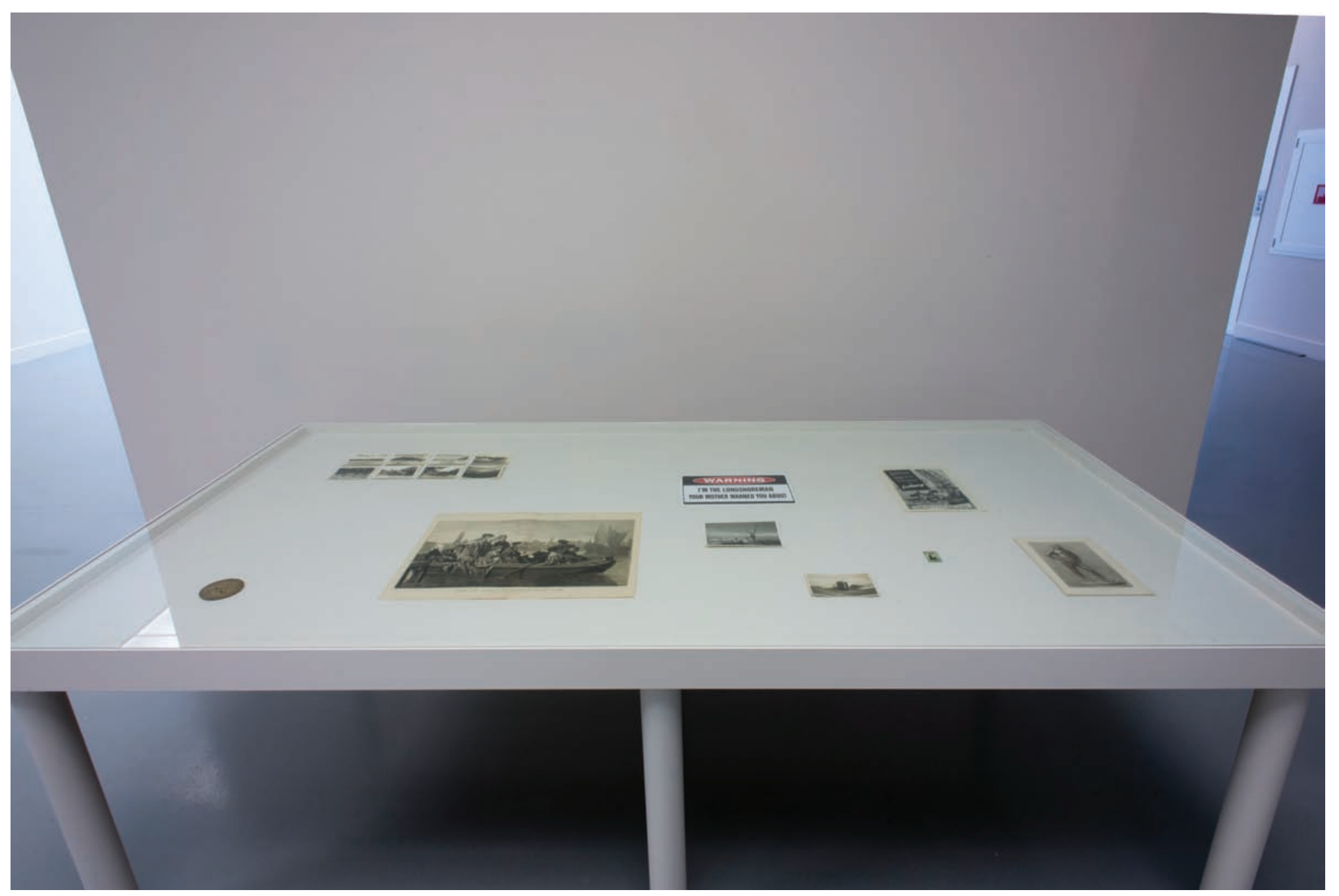

Figure 2: Allan Sekula, Elements from The Dockers' Museum (2010-2013), as exhibited at the Museum of Contemporary Art in Antwerp, Belgium (Summer 2013). OThe Estate of Allan Sekula; Ophoto: M HKA, Christine Clinckx, 2013. Collection M HKA, Antwerp, Belgium. 


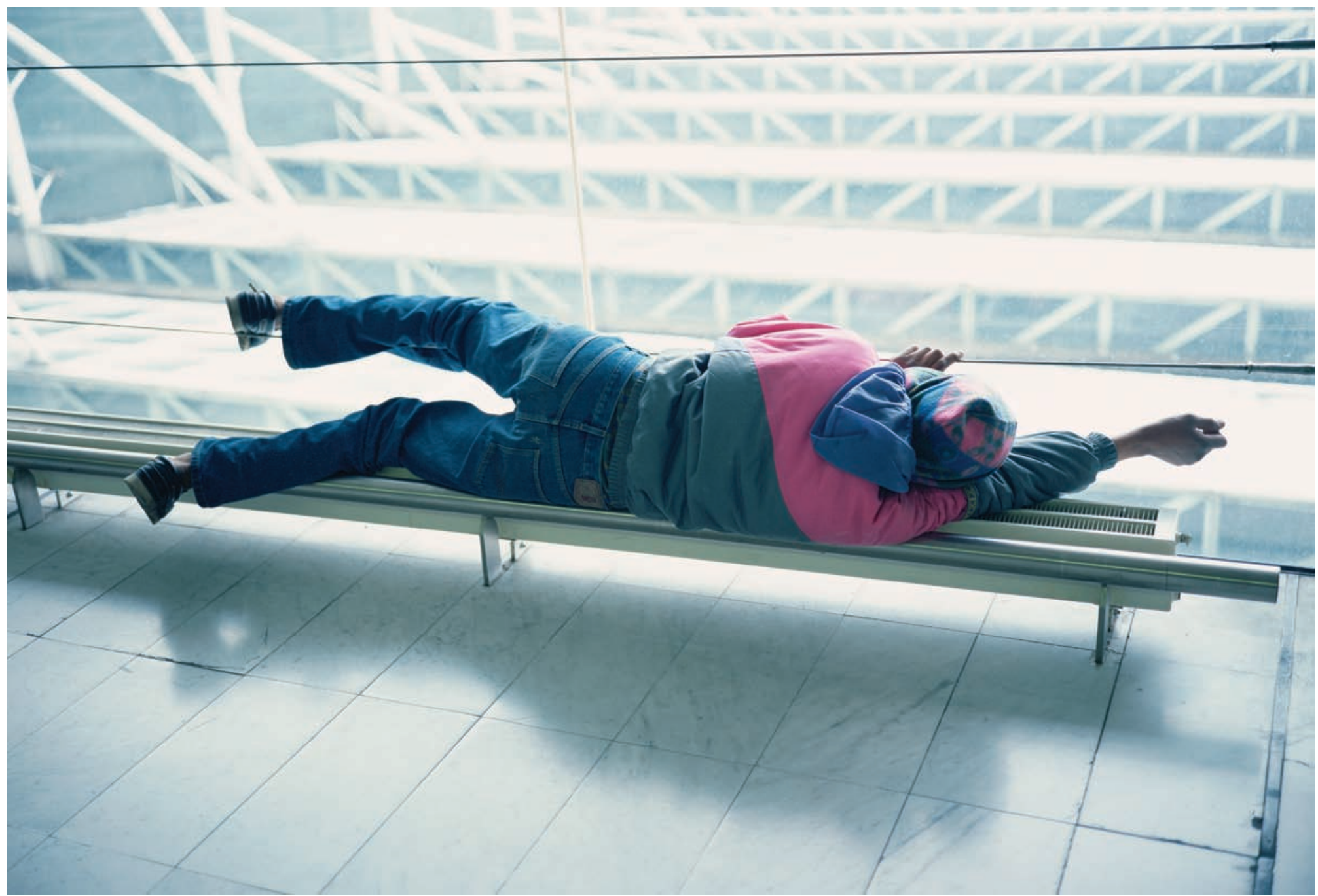

Figure 4: Allan Sekula, Europa, 2005, chromogenic print, 122×193 cm. @The Estate of Allan Sekula. Courtesy Galerie Michel Rein, Paris/Christopher Grimes Gallery, Santa Monica. 
Ronald Reagan continued to distress him. When he was making Fish Story, he recalled recently in conversation, the world had just made it 'one decade into Thatcher'. This led him to create Fish Story's eighth chapter, 'Dismal science (1989/1992)', which documents 'the story of Thatcherite reform along the Tyne in Newcastle'. ${ }^{9}$

The Wall Street crisis was, for Sekula, a further landmark 'asset'. He supported the Occupy movements as much as he could. He relentlessly criticized the narrowing down of privacy that had resulted from the 'War on Terror', yet he always kept his characteristic humour and was always ready to make a private joke, even when seriously ill. From London, he e-mailed a self-portrait made on his iPhone, which he entitled Ant-Werpen [ill. 3], along with the message:

I send a 'thrown hand' (a little late) to all of you from Ant-werpen. Guaranteed photo made in Ant-werpen, not in rainy poshy London southbank full of office spaces to let and lots of old style cafes for construction workers and low-level office people competing with new poshy places for the middle to upper echelons. More surveillance cameras than fleas on an itchy dog. ${ }^{10}$

Sekula had a profound affinity with Europe, not only because of his Polish and English family roots, but also because his work had been well received there from an early stage. In one of our last conversations, we discussed this in relation to one of his photographs, Europa (2005) [ill. 4]. Jian-Xing Too has written of this image:

Europa shows a man trying to sleep on a long narrow baseboard heater at the foot of a glass wall in Charles de Gaulle airport. A difficult balancing act, three of his limbs tentatively rest on a slightly higher cable railing and a low metal barrier that protects the heater from being bumped by luggage carts. Stemming from a desperate search for warmth and constrained by airport architectural details, his bodily posture uncannily resembles the pose of Titian's Europa (in The Rape of Europa, 1562) being carried off by Zeus disguised as a bull. Rather than replicating the latter's dynamic diagonal composition, this Europa lies as horizontally within the picture plane as does Walker Evan's sleeper-cum-unemployed-drifter on South Street in his American Photographs. Indeed, instead of being transported by a divine force, Sekula's Europa is paralyzed by economic forces. Nothing is less certain about the open market of today's European Union than its promise of mobility.

(Too 2012)

Sekula continued to hope that the European integration project would develop further into a model that transcended national hegemonies. A strong European Union could potentially provide a
9. 'Dismal Science' is partly published in Allan Sekula (Risberg 1999: 191-206).

10. A. Sekula, e-mail to the author, 20 April 2012; the title was provided in an e-mail of 26 April 2012 
11. 'Waiting for tear gas [white globe to black]', in Sekula (2003: 87) counterbalance to the excesses of the globalized economy, its chaotic international networks and displaced power concentrations, as well as contributing to increase global justice. As much as he held these hopes, Sekula was also very concerned about the persistent crises of migration and poverty in Europe. As a response he programmatically made and exhibited photographs such as Europa, insisting on showing such sights - familiar to anyone who has travelled in Europe over the past decade - in the context of visual art.

Visual art for Allan Sekula did not necessarily need to look different from the images provided on an everyday basis via the media or through amateur practices. His project consisted in teaching those who were willing to observe his photographs closely to understand what a photographic image actually can or cannot tell us when it is considered along with its captions and accompanying texts. Arguably, one of his work's greatest forces is to be found in this. The educator in him made a strong and convincing case for a spectator who should engage as fully and deeply with his images as he himself had done at the moment of shooting them. In his writings, he explained the importance of learning to see how a photographic image always functions within a contextual setting that contributes to determining its meaning. He was also a key actor in the now historical group of photography theoreticians and practitioners who did away, once and for all, with the illusion that a photographic image can provide objective proof of the reality it depicts. He was the 'anti-photojournalist' par excellence (which is a term he coined). ${ }^{11}$

Nonetheless, Sekula never lost faith in photography's ability to raise critical consciousness in the minds of those who engaged with it. He believed strongly in visual art's capacity not only to take but also to provoke social responsibility. As a general rule, he would never present his photographs in the form of a closed series, but would always opt for more loosely organized sequences accompanied by extensive captions and text panels, which could vary from presentation to presentation. These displays always required a substantial reflective effort from exhibition visitors. For those who made this effort, Sekula's exhibitions accrued the force of eye-opening revelations: not only with regard to questions of how human life has been and is organized, but also about how future change can be imagined collectively. Sekula cherished the imaginary space of freedom that visual art provided him, as he was convinced it was in this context that he could best record and articulate his social commitment.

In his view, visual art needed to develop its activist potential in order to be at all relevant and interesting. Sekula abhorred the speculative relationship that many artistic objects have developed with the art market and he increasingly loathed how many contemporary artists have conceded to this condition. In a recent conversation he talked about fighting as a 'guerrilla against the commodification of art'. He judged the fact that his works might enter the collections of at least partly publicly funded museums and institutions to be of extreme importance. Quoting one of his teachers, Manny Farber, at the beginning of the new millennium he warned against 'art that 'seeks to break out of 
tradition while, irrationally, hewing to the square, boxed-in shape and gemlike inertia of the old densely wrought European masterpiece"' ${ }^{\prime 12}$

In response to a recent invitation to formulate his opinion on Occupy Wall Street, Sekula wrote: "The art world is the most complicit fabrication workshop for the compensatory dreams of financial elites who have nothing else to dream about but a "subjectivity" they have successfully killed within themselves' ${ }^{13}$ In an e-mail to Bart De Baere he specified that - with The Dockers' Museum - he aimed to go against 'the atrocities committed in the names of collectors' and instead wanted to propose a 'sub-sub-underground-anti-connoisseurship' (Sekula 2011). In his last video work, entitled Art isn't Fair (2013), filmed at Art Basel Miami Beach in 2004, he engaged further with these provocations. This four-minute film was made as a tribute to Jean-Jacques Rousseau on the occasion of his 300th birthday and at its end Sekula quoted the philosopher as follows:

I sold my watch, saying to myself with an unbelievable joy, 'Thank Heaven, I will no longer need to know what time it is'. The Confessions, Book VIII.

The time has come to pay further tribute to Sekula's legacy and for us, collectively, to draw conclusions from its important message.

\section{References}

Risberg, D. (1999), 'Imaginary economies. An interview with Allan Sekula', in A. Sekula (ed.), Dismal Science. Photo Works 1972-1996, exhibition catalogue, Normal, IL: University Galleries, Illinois State University,pp. 235-254, p. 238.

Ruchel-Stockmans, K. (2006), 'Interview with Allan Sekula', in J. Baetens and H. Van Gelder (eds), Critical Realism in Contemporary Art. Around Allan Sekula's Photography, Leuven: Leuven University Press, pp. 138-151, p. 141.

Sekula, A. (2003), Titanic's Wake, Cherbourg-Octeville: Le Point du Jour.

- (2009), Polonia and Other Fables, exhibition catalogue, Chicago and Warsaw: The Renaissance Society and Zacheta National Gallery of Art, pp. 74-97.

- (2011), E-mail to Bart De Baere, 22 June.

Thompson, N. (2012), 'Debating occupy', Art in America, June/July, p. 103.

Too, J.-X., (2012) 'Allan Sekula's "Polonia and ..."', http://www.art-agenda.com/reviews/allansekula\%E2\%80\%99s-\%E2\%80\%9Cpolonia-and-\%E2\%80\%9D/. Accessed 3 September 2013.
12. 'Swimming in the wake', in Sekula (2003: 109).

13. A. Sekula in Thompson (2012: 103). 
Van Gelder, H. (ed.) (2005), Constantin Meunier. A Dialogue with Allan Sekula, Leuven: Leuven University Press.

— (2007), 'Allan Sekula. The Documenta 12 Project (and beyond)', A Prior, 15, pp. 210-253, p. 237.

Weil, S. (2001), 'Meditation on obedience and liberty', in Id, Oppression and Liberty (trans. A. Wills and J. Petrie), London and New York: Routledge, pp. 132-137, p. 133.

Hilde Van Gelder has asserted her right under the Copyright, Designs and Patents Act, 1988, to be identified as the author of this work in the format that was submitted to Intellect Ltd. 
